\title{
Arab Ethno-pop as Seen Through the Prism of the Jordanian Youth: Recreation of Locality, Scattering Globalization, and the Triumph of Amusement
}

\author{
Tsonka Al Bakri \\ School of Art and Design, The University of Jordan, Amman 11942, Jordan
}

\begin{abstract}
Music preferences amongst young people provide a significant indicator for understanding their ethnic identities. When quantified and studied, the suggested marker could pose to be a substantial asset that establishes a solid understanding of local music and its role as a socio-indicator for aesthetic preference, and resembles an important aspect of cultural, and ethnic self-determination. Grounded in both historical and socio-cultural analysis, this research will study how music, as a medium, shapes and identifies the given nation's preference in music. The qualitative aim of the research is to explore the underlying meaning behind popular Arab music. The aim will be accomplished by utilizing a reflective terminological study based on a quantitative analysis (in the form of a questionnaire schemed to cooperative students from the 'Yarmouk University' Irbid, Jordan). The data attained from the questionnaire will be employed as a premise for the formulation of the results; and hence, confirming the true importance of contemporary music culture in the development of personal values and musical criteria. Focus is mainly pivoted on modern Arab pop music being interpreted as 'ethno-pop', and interactions found between Western pop and Arabic music will be discussed thoroughly. This conjunction will be looked at as in fact being an exchange of experiences and symbolic norms.
\end{abstract}

Keywords: ethnop-pop; musiqa al tarab, musiqa jadid, Arab culture; identity, youth,

DOI: $10.7176 / \mathrm{JEP} / 11-23-04$

Publication date:August $31^{\text {st }} 2020$

\section{Introduction}

In the nineteenth century, Arab theatre saw a tidal wave of development strongly influenced by Western culture, especially in terms of aesthetics, presentation, and music. ${ }^{1}$ Music actively interpreted every event in the theater, transforming the performance to something, that can be associated with operetta. This newly introduced music, which has been formed as an integral part of Arabic theatre, did win over large swaths of the society and was able to expand beyond the constraints of the Arab theatre, simultaneously to embark on radio, television, and freshly formed film industry. Performers who began their careers in the theater grew to become the most eminent singers of their age, such figures include Farid Al Atrash, Mohammed Abdel Wahab, Abdel Halim Hafez, and Mohammed Fawzi. Alongside the development of TV broadcasting (mid-1900s), the Western model was solidified, thereby revolutionizing music as a product to be sold. "TV shows shape the sustainability of musical preferences and are simultaneously updated and expanded with new artists and trends" (Suna, 2013, 99). Initially, broadcasted musical products were stringently regulated by state commissions. This constraint became void in the 1970s. Through the advent of audio-tape-cassettes, Arab listeners were enabled to consume music on-demand, according to their individual tastes and thus, collectively dictating the production trends in the market. "Greater access to Western musical productions (via recordings) inspired artists to modernize their art, projecting it to their audiences using new formats that assured public interest" (Mutaz, 2010, 81). In the early twenty-first century, satellite channels became widespread (for instance: Arabsat and Nilesat, as well as the Internet and mobile technology. This mass media provided Arabic youth with tremendous access to Western culture input. By this exposure, the public had begun to foster an unhindered appetite towards modern pop-art; one strongly influenced by Western motifs. The amount of TV and Radio outlets have seen consistent growth, so much so "that only within the Palestinian territories there are roughly 50 Palestinian TV and radio stations, both private and state owned, for a population of 3.5 million" (Ayyash, 2002, 35-38). But more importantly, all mass media outlets broadcast the same Pan-Arabic music, based on similar linguistic and cultural essences. The mentioned process was directed by regional leaders (such as Egypt, Lebanon, Iraq, and Syria) conjointly typified by certain extrinsic trends (trans-Atlantic influence), as well as to intrinsically spread 'one's own' local traditions. The new type of music has spread across Arab nations, transforming into music that lacks any frontiers, music for the youth, outstanding source of entertainment.

When defining the exact place of Arabic pop music, importance should be placed upon the delineation of the three major styles within the Arab sonic space: Musiqa Al Tarab (the urban classical art); a style offered by singers from the generation of Umm Kulthum and Abdel Halim Hafez ${ }^{2}$, Musiqa Sha'abie; a style unique in its distinct

\footnotetext{
${ }^{1}$ Hereinafter, 'Western' would refer to the influence within Arab pop culture stemming from Western-European, as well as, North American, and Latin American authors and performers.

Tarab genre adheres to the rules of classical Arabic music (maqam structure and the poetic texts). Tarab (classical art), or fan al tarab, (the
} 
correlation to folklore', and 'Musiqa Jadid ( the new music, or Arab pop;) a style that is associated meticulously with Western influences, and is defined by its pop-modernism and multi-culturalism. Musiqa Jadid has brimmed the gap between Western and Middle-Eastern cultures, and induced the development of a body of literature: Alan Marriam, Howard Becker, Racy, Tagg, Frith, Kerman, Kramer, Blacking, Radano and Bohlman, Shannon, Jonathan Holt, Michael Frishkopf, and many others. Musiqa Jadid exhibited the way western and non-western music synthesized into a brand-new genre that could be defined as a dialogue of differences in which our sense of each other is displaced. Axiomatically, the presumption of such direct consequence of outside phenomenon, namely westernization, brought about the assentation of changes accruing at the very heart of Arab music, touching its core: harmony, (whereby the maqam structure has been transformed), arrangement, structure, text, sonic overview (instruments used), and presentation. As Nettl Bruno (Nettl 1985, 20) said, "[the] modernization can be described as incidental movement in the system or its component in the direction of western music". This reconstruction in the musical archetype, found itself subject of pluralism, hybridity, grouped with dialogism, and multiplicity. The new vision of modernity in Musiqa Jadid can be expressed as a byproduct of a continuum of elements: difference and fragmentation (Featherston 1991), emotional geography (Davidson, Bondi and Smith 2007), individualism (Giddens 1991; Beck 1992; Bauman1998), post-effect of specific lifestyle (Miles 2000), the transformation of social identities (Born 2011), and collective identity (Whiteley 2004). It can be observed how Arab pop music turned into a new kind of identity, an aesthetic of the singular in the multiple, that will be discussed hereinafter as ethno-pop. Semantically, ethno-pop rests upon ethnic and cultural traditions, the desire thereof being to preserve ethnic heritage whilst sustaining the demand for modernity. Explaining the nature of 'own-culture' Williams Raymond said, "Every human society has its own shape, its own purposes, and its own meaning" and "a culture has two aspects; the known meaning and directions, which its members are trained to; and the new observations and meanings, which are offered and tested" (Williams 1989, 4). In this discourse, the cultural revival can be interpreted as integral for "nation-building" (Bahoken and Athangana, 1976, 51), and as an object of nostalgia (Frith 1987) to one's own tradition. In the same context, Brunner proclaimed regarding Cameroon music, "Concerning the creation of national consciousness then, popular music clearly had a firm role" (Brunner, 2017, 46). The emergence of Arab ethno-pop indicates not only specific ethnic affiliation, but also displays various complex relations which exist among ethnic sensibilities and globalization processes. In this sense, one can understand culture as a tool, which may "shape and transform identities and remark new ones" (Valassopoulos, and Said, 2014, 656). Otherwise, simultaneously living within the modern interpretation of traditional forms of music, new forms are easily created and accepted. While portraying ethno-pop to Arab ethnic identity, one can observe it as "nationalism based on a perception of authentic traditions besieged by foreign influence" (Harris 2012, 463).

At the time of presenting the terminology chosen (in the terrain of Arab sonic space); I am to acknowledge its etymology, meanwhile considering its position and contents. The reference for the term 'ethno' should not be seen simply as a token of national and folk creativity, but rather as a display to the context and consistency found within a unique cultural margin. In this sense, that tinge about locality is illustrated initially in terms of semantics and sensibility with conceptual focus to ' $p o p$ ', theoretical meaning surrounding the academic term of multiculturalism. The term ethno-pop is adopted from the author in an attempt to define the clear-cut association of the basic meaning; pop (popular music of globalized generation), and ethno, (reference to certain ethnic determination targeted at the substance) ${ }^{2}$ This term combines several linguistic parameters: symbolic, semantic, referential, and cognitive. Moreover, the very existence and formulation of the ethno-pop is validated by the existence of socio-cultural elements listed below:

- The development of an author's song based on folklore and Western composing technique.

- The development of a novel style of Arab music, producing new elements, and borrowing from different cultural spheres

- The emergence of a great number of festivals, contests, and competitions dedicated to this music style.

- The establishment of a developed infrastructure associated with the dissemination of specific style of music: a music recording industry and satellite music channels devoted to the popularization of ethnopop music products.

- The establishment of a specific network of producers, editors, and distributors.

- 'Boom' in young people's consumption of ethno-pop music, which may to some extent depend on the style (ethnic musical core, based on a uniform ideological platform).

art of tarab), or alam al tarab (the world of tarab), is acknowledged as a specific urban culture. The most prominent performers of $M u s i q a$ Al Tarab are Abedl Halim Hafez (1929-1977), Asmahan (1912-1944), Farid al Atrash (1910-1074), and Umm Kulthum (1898-1975).

${ }^{1}$ Shabi, or Sha' $b$ music is studied by Jeff Callen, who translates it as popular music; Tarik Sabry situates it as the music of the working class, Brian Karl describes it as 'meta genre' and, Lhoussain Simour links it in term of identity. In Jordan, musiqa sha' abie presents a specific style, created for a performance of Dabka (a popular folk chain dance). "Contemporary Jordanian music culture is an expression of both culture and community; it is an expression of the deepest and most profound emotions of the Jordanian populous" (Ghawanmeh, 2009, 20).

2 The term pop-folk has been promulgated by Balkan academia, specifically by authors such as: Sonia Seeman, Wladimir Fischer, Dragićević Ššić, Carol Silverman, Ventzislav Dimov, and Rozmary Statelova 
- The establishment of a social image of a performer associated with ethno-pop (borrowed from Western pop culture) accompanied by the creation of cult figures worthy of imitation.

Nevertheless, the main reason for presenting the term ethno-pop rests upon the collected information from the questionnaire, which shows that young Jordanians do understand, perceive, and define modern pop music as a fusion between local traditions and influences coming from West. I do want to emphasize once again that the type of music weighed is not the direct offspring of folklore originating from the rural communities ${ }^{1}$, but is rather an after-effect caused by the development of urban culture ${ }^{2}$, and is also the succession coming from powerful influences 'from outside'; the Mediterranean region (Greek, Turkish, Spanish traditions), in addition to certain borrowings from American and European pop cultures. The advent of the new style of ethno-pop is advancing towards the displacement of rural folk tradition, thereby resulting into a "locally-rooted genres are disappearing in the light of globalization, and new musical forms are emerging” (Laurent 2007,57).

\section{Jordan in the light of new pop culture:}

Trans-Jordan was formed in 1922, following the dissolution of the Ottoman Empire by the end of World War 1. In 1946, the Hashemite Kingdom of Jordan acquired its independence, and revoked its status as a protectorate of the United Kingdom. However, this fact does not imply that the region was uninhabited prior to the establishment of the Jordanian State. There is real evidence of settlements in the area dating back to the Paleolithic era, after which small kingdoms took root in the territory of modern Jordan; Edomites, Ammonites, and Nabateans, which established large capitals such as Kir of Moab, Petra, and Saltus. Thereafter, the region was absorbed under the domination and influence of the Persian and Roman empires. During the Roman period, several large cities such as Gerasa (Jerash), Gadara (Um Qais), Pella (Irbid), and Philadelphia (Amman) were developed. Along with the expansion of Islam, Bedouin tribes were aided by Islamic warriors as to dismantle Byzantine occupation. Hence, the Jordanian territory entered into Razhidun Caliphate, and later to the Umayyads Empire, thus becoming part of the Arabic Caliphate, which was supplanted by the Ottoman Empire, following a period of internal strife. Ever since ancient times, Jordan has been, and still is, (in part) a tribal country. When the Hashemite family began their rule, commenced by the investiture of King Hussein bin Talal, there was no consolidation under a unified Jordanian nationality. Nevertheless, tribal identity still has its root interior to the present Jordanian social life. "The tribal system in Jordan was established long before the advent of Islam, or even Christianity. The tribes were formed and organized thousands of years ago, and in fact they still persist today, and play a significant role in the sociopolitical realm of the state" (Rowland, 2009, 12) ${ }^{3}$ The formation of Israel, as a sovereign state, caused the influx of millions of Palestinian refugees into the territory of Jordan; which led to a dramatic alteration of the demographic landscape in the kingdom, as it shifted from being a predominantly Bedouin to a Palestinian-Bedouin society. In the late $20^{\text {th }}$ and beginning of the $21^{\text {st }}$ century similar occurrences happened caused by Iraqi and Syrian refugees. The demographic transformations resulted in an increased demand for shaping solid Jordanian national consciousness, built upon the possession of specific heritage, culture, and unique traditions, existing symbiotically with the surrounding tribal self-awareness. Beyond the political necessity, music as deeply implicated in social Pan-Arab cognitive background, and respond to the demand producing new style, called musiqa sha'abie, based on the folk motifs and lyrics referring national pride, and Jordanian self-awareness.

Simultaneously, the late twentieth and early twenty-first centuries have been characterized by the forceful invasion of mass-culture into the social space of the Hashemite Kingdom of Jordan. This occurrence has increasingly melded Jordanian society with expanding globalization, as well as the infusion of Western culture. Whereby the new internet generation has initiated a process of westernization, hence distancing from old traditions and norms. This process revealed fresh horizons and new aesthetics; part of which appears to be the modern Arab pop music. When talking about Arab pop music, the focus should not fall upon a specific region, or Jordan precisely. Formulating Arab pop or musiqa jadid as a term, the holistic accent should be inserted over the 'Arab' as an ethnic definition of unique and unified Pan-Arab culture. This position is based on the fact that Jordanian youth listen to Egyptian, Lebanese, and Saudi singers, and recognize them as their own. The same applies to Egyptian youth who often listen to Jordanian, Syrian, or Iraqi singers and accept them as their own. In this context, "popular music not only has a critical index in the understanding, but also plays significant role in shaping, influencing, and negotiating identity formations among the youth" (Wanjala, Kebaya. 2017 31). The Pan-Arab pop culture is an amalgam of identities and different ethnic traditions, arising from multiple geographic regions that extend from the Levant (Jordan, Lebanon, and Palestine), to Gulf countries, reaching Morocco and Algeria. It

\footnotetext{
${ }^{1}$ Folk music can be defined as "The consistent use of oral transmission, economic and sometimes technological compulsion, which further ensures that each generation will minutely restructure the music to fit its taste and requirement" (Booth and Kuhn 1990, 417, 418).

${ }^{2}$ The impact of urban songs can be found mostly in the form of the poetic input, rhythmic patterns, and general musical line. Many songs are lyrical and romantic, in the case of Lebanese tradition, (Fairuz). Her ballads can be viewed as a continuation of the traditions set by Umm Kulthum and Abdel Halim Hafez. Furthermore, one may find shrewd, tricky, and humorous songs, the legacy of the Egyptian film and theatre comedy.

${ }^{3}$ The most prominent tribes are Beni Hassan, Aduwan, Abbadi, Beni Haled, Srahan, Beni Saher, and others
} 
is a culture based on self-awareness of many ethnic groups and countries, which share same language, traditions, and aesthetic values. This culture is a pure expression of the reflective formulation: 'who are we?' and 'how do we select and combine sounds to express ourselves as one of a whole?'. In terms of Arab ethno-pop, I will visualize this specific phenomenon as the fruit of a modern music style that is a product of international societies, which have determined themselves as Arabs, and which are splayed throughout Arab countries. The phenomenon is recognized by each one of these communities as local, and as their own. Throughout the study, I must emphasize that the Jordanian youth adopt this specific stance regarding their own music, namely the Pan-Arab ethno-pop, produced from all over the region. This consequence is not just a result of identical language, traditions, and values, but mostly consequence of shared conception of the world evident to young Arabs.

\section{Cultural and Sociological Results of the Questionnaire:}

The paper-and-pencil questionnaire presented aimed to investigate the musical preferences of young Jordanians. The inquiry forms were handed out to one hundred students of the Yarmouk University, Irbid, Jordan (in 23.04.2019). These were filled out mainly by Jordanian citizens (two foreigners, nationality: Sultanate of Oman). Students participating in the questionnaire were selected from the Music Education Department (eighty people), and the Music Department (twenty people), College of Arts. The students come from medium-income families settled in the Northern part of Jordan (Irbid, Husson, Ajlun, and the surrounding villages). The age group of the individuals involved in the questionnaire was as follows: 76 persons - aged 21 years, 17 persons - aged 22 years, and 7 persons - aged 23 years. 64 students were females, and 36 were males. ${ }^{1}$ The questionnaire was created to determine the parameters spotlighting several key issues. The first topic of concern was the place and meaning of modern Arab-pop music, as well as social-cultural dynamic of the phenomenon from the perspective of young Jordanians, Secondly, the questionnaire aims to determine whether Musiqa Jadid is recognized as 'its own' or as a descendant of globalization processes, whether the youth recognize Arab pop as a byproduct of Western influences or as a pure local consequence. The final aim is to define the role of globalization from the perspective of aesthetic and sociological everyday occurrences. The idea behind the progression of the chosen questions, and ostensibly of the line of inquiry itself, is positioned over indirect nudging of the participants to reveal what is significant and meaningful to the research itself. Essentially, what is the substance of pop music to the young Jordanians; where is music placed in their hierarchy of needs and wants, and how do they situate it within the space of interferences, differences, and fragmentations of the contemporary life.

The first line of inquiry relates to the intention of discovering the position of music in the every-day life of the new generation of Jordanians, therefore determining the importance of music to the participants.

1. What is your hobby?

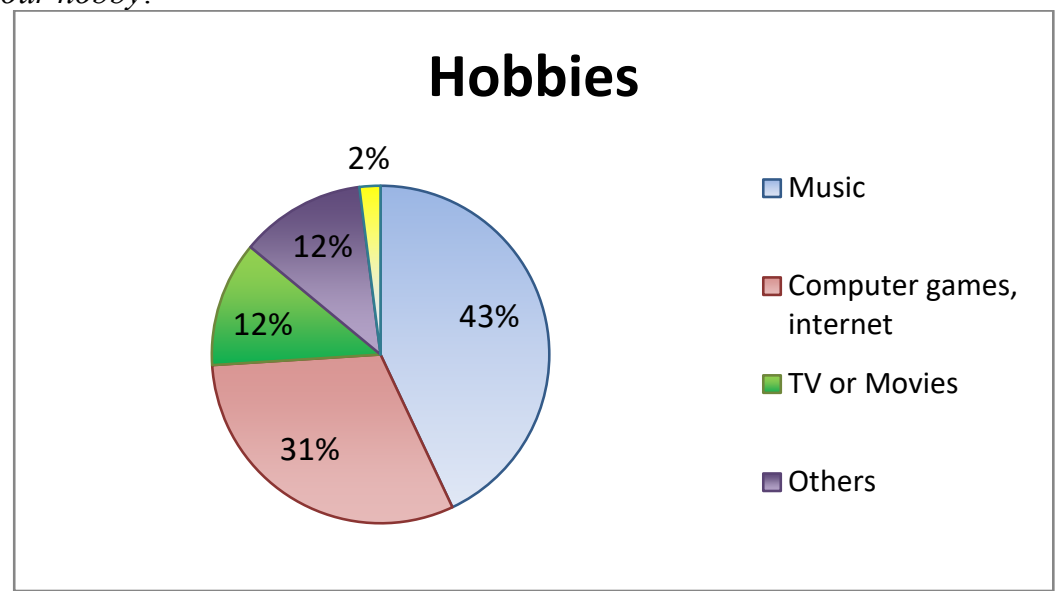

The results reflect the major importance of contemporary music culture to young Jordanians in comparison to other named hobbies.

\footnotetext{
${ }^{1}$ The qualitative approach was based on Foddy, Gillham Saris, Strauss, Corbin, Gallhofer I. N., Mellenbergh G.J, Flick and Steinke and Likert
} 
2. What style of music do you prefer?

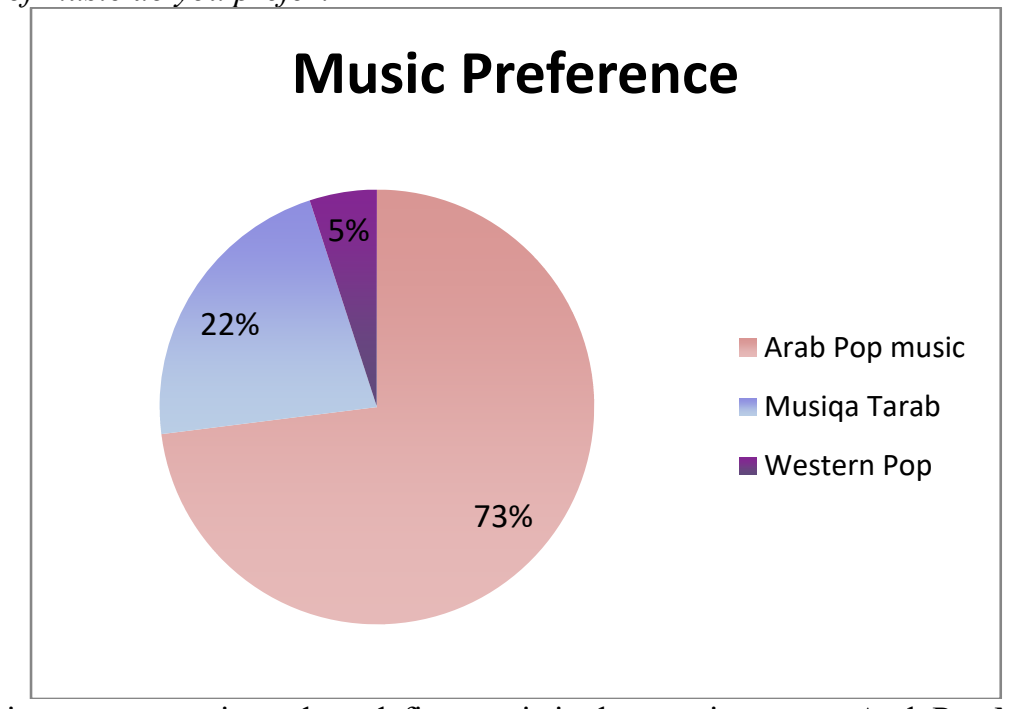

With this question, an attempt is made to define music in three main groups: Arab Pop Music, Musiqa Tarab, and Western Pop Music; thereby ascertaining the participants' tastes in music. The answers received conclude the view stated within the paper, namely the existence of an unambiguous preference for music characterized by local, and oriental essence, that is influenced by western and modern pop sound.

3. How would you classify the modern Arab pop music?

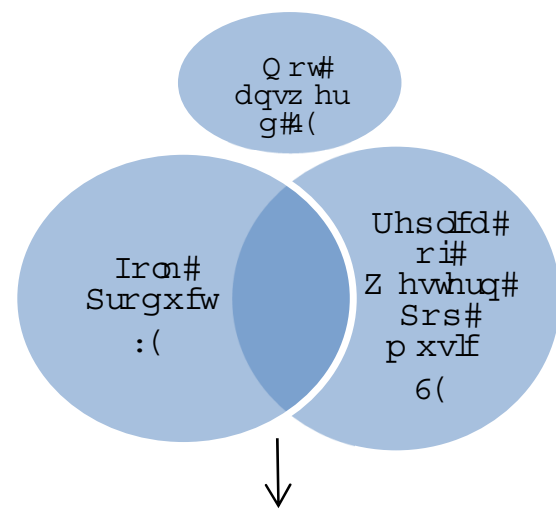

\section{Mix between Western Pop and local Folk tradition - $\underline{89 \%}$}

It must be noted that the individuals involved in the questionnaire defined contemporary mass-mediated Arab pop music as an ethno-pop product. This question was significant to the research, as it precisely shows the participants' concept of modern Arabic music. The answers confirm the appropriate choice of the term, namely ethno-pop, as representative for previously discussed Musiqa Jadid.

The following question interrogates the influence of the product, created by media, the pop performer as an image of a cult figure. This question is rather valuable because it reflects the importance of visual presentation of a musical product, which as stated earlier is a trend born out of the Western music industry.

4. Does the outer appearance of singers influence your preference towards them?

\begin{tabular}{|l|l|l|l|l|}
$\begin{array}{l}91 \text { persons } \\
\begin{array}{l}\text { Strongly } \\
\text { influenced }\end{array}\end{array}$ & $\begin{array}{l}\mathbf{4} \text { persons } \\
\text { influenced }\end{array}$ & $\begin{array}{l}\mathbf{2} \text { persons } \\
\text { Neither Or N/A }\end{array}$ & $\begin{array}{l}1 \text { person } \\
\text { Not influenced }\end{array}$ & $\begin{array}{l}\text { person } \\
\text { Strongly } \\
\text { not influenced }\end{array}$ \\
\hline
\end{tabular}

What I would like to emphasize is the enormous impact of the image, the finished market product in the form of a pop idol created from the musical industry. Viz. the specific purposeful build-up of alluring, vibrantly colored, and striking images advertising and selling themselves, being worthy of imitation and admiration. The answer presents the colossal brunt of mass-media products and how they impact the preferences of Jordanian youth. The above question labels pop music products as being built upon consumption practices, and as being dependent on multimedia in the promulgation of specific lifestyles (Miles 2000). 
5. Do you think that modern music influences our contemporary society?

\begin{tabular}{|l|l|l|l|l|}
$\begin{array}{l}99 \text { persons } \\
\text { Strong } \\
\text { Influenced }\end{array}$ & $\begin{array}{l}\text { 0 person } \\
\text { Influenced }\end{array}$ & $\begin{array}{l}1 \text { person } \\
\text { Neither } \\
\text { or N/A }\end{array}$ & $\begin{array}{l}\text { 0 person } \\
\text { Not influenced }\end{array}$ & $\begin{array}{l}\text { p person } \\
\text { Strongly } \\
\text { not influenced }\end{array}$ \\
\hline
\end{tabular}

I am bound to point out that the pop industry, with its lyrics, images, and ideas, does not merely influence but dictates, to a significant degree, the mindset of the recipient of the musical product, defining and creating bases and trends in the spheres of interpersonal relations, and more broadly; the community. Therefore, the Jordanian youth openly declare the influence of the music industry over their social behavior, recognizing the significance of modern pop in their everyday life.

The next two questions are general, to ascertain a broader understanding of cultural appropriation and transmission. Thusly, one may inquire about the understanding of young Jordanians concerning processes of multiculturalism and shifting paradigm of their own culture to cultural diversity.

6. Do you think that Western music culture exerts any influence on modern Arab music?

\begin{tabular}{|l|l|l|l|l|}
\hline $\begin{array}{l}83 \text { persons } \\
\text { Strongly } \\
\text { Influenced }\end{array}$ & $\begin{array}{l}7 \text { persons } \\
\text { Influenced }\end{array}$ & $\begin{array}{l}4 \text { persons } \\
\text { Neither or N/A }\end{array}$ & $\begin{array}{l}2 \text { persons } \\
\text { Not influenced }\end{array}$ & $\begin{array}{l}4 \text { persons } \\
\text { Strongly } \\
\text { not Influenced }\end{array}$ \\
\hline
\end{tabular}

The higher percentage of Jordanians who are aware of and register the influences of Western music is rather significant. This confirms the merger of Arab musical tradition into a common pop culture or the multicultural stream. What is noteworthy is that the Jordanian youth accept and acknowledge the definite impact of Western pop-culture into their own sonic space, thereby showing tolerance and acceptance towards globalization.

7. Do you find globalization to have a positive homogenizing effect on music?

\begin{tabular}{|l|l|l|l|l|}
\hline $\mathbf{8 4}$ persons & $\mathbf{8}$ persons & $\mathbf{3}$ persons & $\mathbf{4}$ persons & $\begin{array}{l}\text { person } \\
\text { Strongly Agree }\end{array}$ \\
Agree & Neither or N/A & Disagree & Strongly Disagree \\
\hline
\end{tabular}

The final question aims to answer whether globalization, from the perspective of the Jordanian youth, signifies an inevitable effect on music, and justifies to what extent are the participants welcoming towards the fact that their music does merge with foreign civilizational elements. Moreover, it asserts the point that globalization, in the era of the Internet, washes away all barriers between various musical paradigms, and produces a homogenous mass-mediated product of diffusion and syncretism (Lopes, 1999, 25; Guilbault, 1997, 31). Received answers illustrate the comprehension of Jordanian youth, that music culture belongs to an analogous global flow, and is the result of multi-national stream invasion into one's local musical space. Furthermore, the answers demonstrate this fusion, combined with a recognition of the named forces as a positive.

This questionnaire aimed to accentuate the considerable impact of mass-music on youth as well as to present how young Jordanians view and define the Musiqa Jadid, how they situate and perceive it. The questionnaire attempted to answer the question of what could assist us in understanding Arab pop music as a world phenomenon, which involves ideas consenting paradigms as 'we and others', meanwhile taking into consideration that music does not exist isolated within a certain geographical space, but is a vital, alive, and variegated process (Alan Lomax 1968; Berkowitz 1972; Shepherd 1991).

A few basic conclusions can be drawn from the questionnaire. The first conclusion is that young people in Jordan devote a huge portion of their time to music, where the natural consequence of this has been that modern music icons introduced new trends into their lives. The influence of music can be summarized as Slobin puts it: "It is clear to many trained observers, that even when people seem to be reviving things, that is, exhuming them and breathing life into them, what they get is something new" (Slobin 1983, 37). The second conclusion is that a new aesthetic system had emerged, which is hinged upon the formation of current adored images of beautiful female singers or handsome male singers worthy of imitation. These idols must have an attractive exterior, be well-dressed, and be influenced by Western stylistic. In this way, a star is produced, becoming a reflective model and a projection in young people's minds. The third conclusion is that strong interest has been registered towards the local music culture, which has been ethnically justified and evinces with great precision a consolidated national identity, and a sense of belonging. On this platform, one can refer to the theory of the racial and the ethnic theory (Radano and Bohlman, 2000), the authenticity of one's own group (Hill, 2007; Wilson 1973), the infinity of different worlds (Butt, 2002,17) and spaces (Bennet and Rogers 2016, Gervais-Lambony 2010, Whyteley 2004). The fourth conclusion is about acceptance of the fact that music is becoming an art with no frontiers, whereby the borderlines between one's 'own' and 'the foreign' are blurred, and the eclecticism of the processes, mutually supplemented and intertwined, is willingly accepted. In this regard, one can be precise by citing Aziz who emphasized "The young generation, especially in urban areas are more tolerant to foreign ideas than the older generation" (Aziz, 2010, 86). The fifth conclusion is that a mass preference has been registered towards contemporary Arab performers of up-to-date pop sound, typical bearers of the idea covered by this paper: viz. not just singers from Musiqa Jadid, but ethno-pop performers upholding the impression of Western pop music idols, thus presenting a music with a tinge of traditional elements. The preference to local sound could be understood "not merely as something particular to the youth, but rather as a key element in their collective cultural awareness 
and a major contributor to their generational identity" (Bennet and Rogers, 2016, 478). Finally, globalization is freely accepted and recognized not as a restriction, but as a resource which "potentials [are] far beyond those of the local market" (Hayward 2012, 72). Seen from this perspective, one may perceive the current Arab ethno-pop culture as "[the] subject of social processes" (Zolberg 1990), which intermingle and coexist alongside with the nexus of a modern musical product. Therefore, nowadays musicology, cultural sciences, ethnology, and sociology become interlaced and elaborate upon one another, hence generating a situation in which they should be discussed simultaneously, transforming any research connected with contemporary culture to a multi-scientific matter.

\section{Ethno-Pop as a context}

Classification of the modern music in the Arab world (musiqa al arabyyah) was presented by Salwa El Shawan, $(1980,86)$ dividing it into three major categories; musiqa al turath (traditional), musiqa al jadid (new) musiqa al sha' $i$ ' $a$ (widespread), whereas the two last categories overlap each other. At this point, I am tempted to focus on the fact that musiqa sha'abie inserted within the second category, as compositional, melodic, and rhythmical modes is completely different than its Westernized sibling. Ali Jihad Racy 1981, Davis 1996, Danielson 1996 also examined the culture-musical dynamism and tendencies within the popular Arab music. Before turning to my analysis of ethno-pop, I would like to point that Pan Arab music in the frames of musiqa al jadid is rooted predominantly in the local musical tradition (George Yousuf, Fadel Shaker, Majida Roumi) characterized by sophisticated use of oriental rhythmic and melodic patterns within the instrumental and vocal forms, enriched with some Western elements. Simultaneously, another style exists, within this wide category, one featuring dance beat, electronic sound, harmonic clichés, simple melodies, easy digesting texts, attractive singers; a style that applies widely Western instruments, what lead to shift in the general sonic picture of the musical product. This is the ethno-pop; popular music, producing music stars, transformed from auditory to visual mediation; pop music penetrating the social space, tempting even tarab singers to perform according to Western idioms in search of selfadvertising and commercial success. This is the winning product of globalism, based on market forces, technology, and synergy. Ethno-pop persists as a symbol of contemporary Arab youth, and as a subject of human behavior determines a handful of social mechanisms and cultural interactions that typify certain links between Jordanian millennials and the international community of new internet generation. The stylistic that is demonstrated within the matrix of ethno-pop is not always recognized by Arab researchers as a subject worthy of investigation. This specifically is what provoked me to form an association with the following statement made by Nettl: "The anthropological approach encourages ethnomusicologists to also study such phenomena which a certain society is not inclined to discuss as music, and even less as art" (Nettl 1983, 24). In fact, Arab musicologists give little attention, if any, to popular culture, which was made evident by Michael Frichkopf, Dickenson and Harbert. Regarding the social and cultural challenges, transmission and presentation of ethno-pop, local researchers point towards the encroachment of Western culture into Arabic music, which many consider as a loss of authenticity. Expressing such concerns, many have lost the bigger picture of the symbolic social context of the event, or even the fact that ethno-pop is a result of shifting socio-economic and socio-cultural paradigms, otherwise, a mere consequence of responsive flexibilities aimed toward the Western model of democracy and life. Ethno-pop music can be viewed as an object of human behavior, and simultaneously a cultural substratum of aesthetic and social conceptions. Therefore, the west-ward shift can be interpreted as a general willingness of exploring new horizons, thus breaking away from some traditional conservative norms. Also, a desire idolizing innovation and modernity, all of which catalyzed by a new universal generation. Local studies, fixated on musiqa tarab and folkloristic still dominate the academic landscape, leaving pop music under-explored. Ethno-pop has been silently labeled in the academic circles as a subject of low importance, stigmatized by its Western influence, modernity, and simplicity. Regardless of the notable researches of Racy, Frichkopf, Azziz, and some others, Arab academia is a retreat from the topic, overwhelmed from nostalgia toward symbols of an earlier time. Simultaneously, the ethno-pop is conquering public imagination, capturing novel historical moment, reconfiguring cultural identities. Looking back to the fundamental work of Jose Ortega y Gasset, The Rebellion of the Masses one can read that "The masses aggressively make their claims to occupy the best seats in the Theatre House" (Ortega y Gasset 1989/1930, 110), and wonder how precisely the author predicted the future path of mass culture. Much of Arab public aesthetic and mass demand for ethno-pop cross-fertilized the popular music, legitimizing the co-existence of features such as homogenization and differentiation, which are not rejecting each other, but subsist as integral constituents. Despite any arguments that are aimed against ethno-pop as part from musiqa jadid, something which could be interpreted as an attack on 'mass culture', ethno-pop has actually proved itself as a specific style; one which resonates with the demand of the listeners, and more specifically, with the demand of the youth. Notwithstanding the marginality and academic demonization of Arab Pop, ethno-pop has grown into a predominating, globalizing, transnational, and determining music style. Ethno-pop, in its presentation demonstrates a type of creational process based upon totally new aesthetic preferences and transmitted by novel models of intersperse cultural forms. "Experience of culture today is no longer between a listener and work of music, a viewer and a painting; there is a whole host of people and technologies and networks that mediate between the people and cultural form" (Taylor. 2013, 760). 
Thusly, contemporary culture in the Arab world has been morphed into an innovative process typified by shifting paradigms, stylistic borrowings, and collaborations, all of which penetrate through the medium of mass-media and lead to the promulgation of the ethno-pop by the youth. This music requires to be framed and explained, lived, and experienced, introduced, and accurately described.

Arab ethno-pop, as earlier discussed, can be depicted as a hybrid of folklore traditions, contemporary arrangement, use of diverse musical instruments, and as a mosaic of local and foreign elements under the domination of a common vision and aesthetic coverage. If one attempts to specify the phenomenon will face a typical example of a merger in historical trends; continuity, discontinuity, and cycles, centered over a specific selfpurposeful mixture of sources, and subordinated to and integrated by the idea of being omnivorous and commercial. I have defined ethno-pop as an offspring of folklore because it implies the existence of continuity, heritage, and routine, regarding methods, actions, and practices. "Musical practices in the present are shaped not only by past experiences, but also by ideas, feelings, and beliefs about the past" (Bithell, 2006, 4). The existence of folklore, as an element of culture, is essential for the ability of Arabian ethnos to self-identify. Moreover, it is a key for the identification of cultural tradition in its capacity of a medium for self-recognition and belonging. "The songs provide a sense of authenticity, cosines, joyfulness and happiness, connected with the ideas of national and regional culture" (Suna, 2013, 97, 98). "The most important part is not that the music 'is' authentic in a way that it can be traced to real people playing music in traditional ways - but that it merely signifies this kind of authenticity" (Taylor, 2012, 177). This concept of folk experience is not exclusive to Arabia, it can be found in the Balkans (turbo-folk, pop-folk, chalgia). Although this study is dedicated to the Arab cultural area, the symbolic-value judgments revealed (cultural identity) often echo those available in South-European or Far-Eastern regions. In the mentioned cultures, eversion towards folklore is often perceived not only as an attempt for self-identification, but rather as a 'cry' for distinction from the homogenizing trend of globalization and "resistance to the hegemonic structures of established genres of modernity" (Briggs and Bauman, 1992, 149). The copulae between folklore and pop are brought about via the recreation of heritage into a new form, which is one of the most fundamental creative techniques in modernity (Boden 2004, Lessig 2008). Riling into ethno-pop, folklore has undergone an ideological change. Hereafter, al turath became watered down and de-structured ideologically for the sake of servicing the new requirements and tastes of the youth. Therefore, the shattering of intrinsic traditions is the aftermath of the attempt to obtain certain markers of modernity, as well as commercial viability. Respectfully, this process was referred to by Colin Sparks, who has identified globalization as a sign of modernity which destroys locality and replaces it with "world market models" (Sparks, 2000, 70-78). Thus, Arab ethno-pop has demonstrated its characteristic of crossing boundaries beyond the well-known musical subject of folklore. Thus, entering broad spheres like cross-cultural, semiotics, and hermeneutics. And most notably, it displayed a retreat from the established paradigm. Whereby, the piece of work considered as art's fundamental value factor, become replaced by the person, with his/her current tastes, preferences, and requirements. Ethno-pop or contemporary mass culture in Jordan and Arab world has undoubtedly destroyed certain traditions - and still, it does- but at the same time, ethno-pop does prove to be the folklore, since it is presented as a repertory for popular entertainment and is based on aesthetic traditions and cultural prisms sought after contemporary tastes of local people.

\section{Ethno-Pop; Music for Entertainment.}

When discussing Arab ethno-pop, one can link it to 'the theory of entertainment', or to music resulting from Epicureanism; the music composed and offered for the sake of pleasure. Popular culture on the one hand a culture of 'the people' (the consumers), who constitute it as a meaning. On the other hand, popular culture is "an industrially made and distributed phenomenon" (Fiske, 1992, 23). This kind of music can be associated with the pre-cultural and amusement. By its means of expression: sound-beat (melody and rhythm) and gesture-movement (dance), from the very moment of its inception; ethno-pop has carried a message and power to entertain. This Epicurean pop culture has taken a leading role and has turned into the object of a multitude of studies, from the late 20th and early 21 st century, describing it as "[the] music of resistance and acquiescence, utopian idealism and nihilistic hedonism" (Reynolds, 1998, 92). Elgar Moren had defined it as: "And now the barracks of the fair gatherings and the nickel-odeons (halls for cheap film shows from the early 20th century) set off the second industrialization, the second colonization, infiltrating the great Reserve that the human soul is. The soul is the new Africa, which the new streams of movies begin to chart out" (Morin, 1995, 27). Merely a few decades later, musicologists have been examining the result of his statement; homogenization, prototype rhythm (African or Latino), and uniform vision of the pop-culture. We coexist daily in a world speckled with the diverse; we are living in a rapidly changing world, wherein 'the foreign' is increasingly more often living alongside us and is tempestuously entering our personal space. Mixing West-East, and North-South cultural models lead to unification and that fusion has not yet ended. It is almost certain that the music of the future would be a hybrid and "even the idea of identifying/going back to its sources will become an anachronism"(Toop, 1995, 14). The acknowledgment of the suggested fusion was shown in the questionnaire, along with the acceptance of young Jordanians towards it. During the process of adopting new coalescence, no frontier music had been recognized or approved, because, in 
its very essence, it acts as an esteemed way of entertainment for the new millennium. Arab ethno-pop has grown to be a symbol of a generation, an industrialized product produced for mass-consumption. "And today, wherever there is music, there is money" (Attali, 1985, 3). The presentation and the very quintessence of modern ethno-pop has led to heaps of discussions within the Arab community, from which two major trends have arisen. The first trend, that of traditionalists, denied the influence of Western culture upon values present in musiqa tarab. "Arab scholars, intellectuals, music connoisseurs (sammi'a), trained musicians, and social conservatives have frequently criticized newly emerging mediated music as aesthetically inferior and low-brow, overly commercial, and excessively Westernized" (Frishkopf, 2010, 5). Ethno-pop was received with much controversy, mostly due to its visual presentation of male and female performers who echoed the West pop stars stylistic. Some videos with provocative images of "barely dressed ladies" "have often triggered angry responses and accusation that the media is painting Western ideas in the minds of Arab youth" (Aziz, 2010, 86). Shannon Jonathan Holt (2006) who examines the music videos and public images of stars such as Shirin, Ruby, Nancy Ajram, and Haifa Wehbe, describes them as "intensify female seductive persona". Additionally, male singers who used sex appeal in the form of sexy female dancers in their music videos, were viewed as 'clowns'. Whereas the author argued that sexiness in the form of 'skimpy outfits' and 'suggestive dancing' was fundamental to female singers' success in the industry. Kraidy (2008) discussing the same topic argued that the singers' visual style and physical attractiveness have become more important than their voices. In Kraidy's research, one could find characterizations such as 'erotism' and 'pornographic' video clips. Similar sentiments could be found in the studies of Al Barghouti and El Khachab (In Music and Media in the Arab World, 2010, edited by Michael Aaaron Frishkopf). Some academics showed more tolerance to the ethno-pop industry grounded upon positive signs of liberation and liberalism, expressed within. (Frishkopf, Abdel Fattah). Monitoring the socio-cultural atmosphere in the Arab world; the traditional conservatism, family-valued moral and religious codes, Frishkopf mentioned in his research that pop music is sending strong messages of freedom and "Despite conservative opposition to sexy clips, they are widely consumed-if not publicly imitated-by the Arab public" (Frishkopf 2010, 31); Though the considerable impact of Islamic conservatism and "ironic contrast between street and media live"; "Predominantly male patrons crane their necks to watch attractive, semi-nude dancing females, while fully veiled woman passes by their street" (Frishkopf, Ibid). The quoted observation resounds the misogynistic context in some researches of Anglo-Saxon academia (Adams and Fuller, 2006; Story, 2010; Gourdine and Lemmons, 2011; Cundiff. 2013). Sometimes, Arab and foreign musicologists' denial of ethno-pop reach a degree of pure abhorrence "and, lest I be mistaken for a fatuous cheerleader for 'the music of the people,' I will make it clear that in my professional and personal judgment, much of this music is terrible" (Gilman, 2014, 20). Despite the partial negligence towards ethno-pop, young Arabs still seek and embrace the new genre. The beguiling exterior of their musical idols breaks away from the traditional archetype of conservativism and locality. Ethno-pop challenges stereotypes and explores sexuality; it presents the artist whilst teasing the eye with erotic hints. Indubitably, the modern paradigm of the bard retreats from the classical representation of 'divas' such as Umm Kulthum and Fairuz, who lean on traditions (Lohman 2010), and focus on 'stars', probing the limits of social tolerance, advertising themselves by erotic and frivolous manners.

Ethno-pop promoted by attractive dances along with provocative presentations, often about to cross the borderline of what is viewed as vulgar, recreated modern man's need of 'letting off steam' in the midst of movement and sound. Through dance, rhythm, pure motion uninvolved in music, the Arab youth gives in to the game. Freedom in expression, becomes the greatest determinant of market-share and hence the spread of ethnopop music in the Pan-Arab world (simultaneously to similar processes taking place in other areas around the globe). This phenomenon occurs as a result of the desire of young people for a new vision, an aesthetic that is more modern, free, distant from traditional taboos, and ultimately more Western. Young Jordanians, as well as their peers from neighboring countries, sought self-expression by gradually distancing themselves from their tribal tendencies and conservative traditions in search of new unrestricted and playful voicing. Contemporary artists launched this trend, incorporated it, and converted it into the ethno-pop. The music of fusion conquered the sonic space in Arab countries.

Multiculturalism is no novel trend on a global scale, but rather "the exchange is as old as human history" (Braudel, 1982, 225) and this "exchange may take many forms" (Diawara 1998, 151). Cross-cultural effect in ethno-pop may be defined as an exchange of artistic messages, composition techniques, instrumental interchange, contextual ideas, and visual presentations; a label of commercial origin which refers to "an amalgamated global market place of ethnic commodities which tells us the story about intersections of transnational capital, global economic niche expansion, technological ubiquity, and the contradiction of aesthetic pluralism and product homogenization" (Feld, 2011, 40). Stretching from Europe to the Balkan countries (chalga, trubo folk, rebetika), and from the Afro and Latino rhythms in North America to the Arab countries, the tempestuous pop sound and 'open' vision, is concorded as being a kindred cosmopolitan type of music. We are witnessing an outstanding cross-cultural process. It can be identified, as a global trend of interest in pop-sound, instruments, arrangements in a dance style, unified vision, movements, choreography, and an intensive pursuit for an integrating electronic beat; all of which lay the foundations of the hybrid type of music. This complicated traffic of sounds is two-way, dialogic. 
While watching some inter-ethnic interrelations, we can say that American music is becoming Africanized, but African music is also Afro-Americanized" (Feld and Charles, 1994, 239).

The most important element determining ethno-pop is the striking association of the music featuring visual creativity. It is not only about the multimedia products, but also the very process of making music that 'is for sale', for entertainment. The guiding idea in the creation of a music product, vision, and expression, is being shaped by the premeditated success and financial realization. A musical background has been determined as one that is 'winning' and 'sellable', mainly when it is based upon specific requirements such as vision, choreography, and presentation. The music that penetrates urban youth. It is a difficult task to associate Arab ethno-pop to any specific audience. This is because the audience is not marked by shared religion, class, or educational marker, but instead tend to cover a broad-ranged social stratum. In reality, this situation has been induced by the new political and economic situation present around the world. The occurrence is characterized by extensive mass globalization, global access to 'high bandwidth knowledge', and a two-way uniform aesthetic, based on the main purpose; to sell and entertain. Therefore, this multi-cultural dialogue places ethnomusicology into a new situation in which pop music becomes an object within the context of the social stereotypes riling into the uniform dynamic stream, "typified by fragments 'from outside' and 'from inside', with influences streaming in from both the local and global” (Negus, 1996, 138).

\section{Musical Articulation of Arab Ethno Pop.}

In order to shape the obvious features marking the ethno-pop, I will observe some specific lineaments implementes in the songs of Arab pop singers. The examination will follow the ethno-pop expression; music drifting away from its traditional roots, colored with Western music features; music linked with specific culture, ethnically determinate and folk shaded. I argue that novel expressions, finding their place in Arab music are direct responses to globalized society and result in the demand of young people. Ethno-pop looked at from a global scale, has isolated itself from classical Arab tradition essentially, reconstructing itself into a new model of music, one that is self-expressing through ethno identity, and one which fosters external foreign elements. "The 'fusion of horizons' operates through developing new vocabularies for comparison, by means by which we can articulate these contrasts" (Teylor, 1994, 67).

\section{Western technique of composition}

There are some notable marks, suggesting the shift of local compositional technique toward Western patterns of composition. Arab music was traditionally based upon horizontal, melodic understanding of the texture in contrast to the Western musical paradigm, which is built upon the vertical, harmonically positioned text. Arab maqam tradition interpreted the vertical, melodic line/idea as a continuum incorporating some modal, emotional or rhythmical variations. This tradition gradually transformed and harmonization upon the principles of Western pop composing techniques was adopted (Amr Diab, Tamer Hosni, Alissa). "Arab maqams are non-equal temperate systems, even though they were adopted to be harmonized" (Signell, 1977, 46). Progressively, the chordal structure averted modern Arabic music, distancing it from its custom linear roots, further asserting the dominance of simple chordal clichés, so typical for Western pop. In most ethno-pop songs this compositional import is obvious, and can be described as introducing simple chord progressions, supporting easy recalling melody, while native oriental sound shifting to foreign, diatonic sound (Hatim Ammour Aual [The first]; Abu Yusef Talat Daqaek [Theree minutes]). Therefore, it is safe to say that the diatonic scales have increasingly infiltrated Arab melodies (Fadel Shaker, Rouh [Be gone]). Examining ethno-pop, one can observe short songs (far shorter than traditional ballads and rhapsodies ughniya, and wasla of Umm Khulthum and Abdel Hafez); songs with predominant accent on the dance beat. Otherwise, "melodic-harmonic clichés, simple texts, visualized by attractive singers. These songs are "fast food for young" (Marcus, 2007, 161). The structure converted from muqaddima, dawr, and qasida to simple AB or Rondo form. Ethno-pop presented new, short forms, in which all sounds are compacted controlled by dance rhythm, without pauses, rests, in contrary to the extended, dense, full of breaks and silences musiqa tarab.

Adoption of a new rhythmic patterns

Arab music is built upon specific rhythmic patterns known as iqa'at, strict formulas, which apply to different maqam modes. It is safe to state that precisely the maqamat and iqa' at are the basic elements providing specific oriental essence to Arab music. Nevertheless, multiple pop songs are increasingly using the fashionable Latino stereotypes, as well as hip-hop beats. (Omr Diab Taaally maak, [Come with me]). Ethno-pop though still based on the traditional oriental rhythm submit to more movable, provoking, collective, pulsating, and resonating impulse of dance beat.

\section{Incorporation of new instruments}

Electric guitars, saxophones, and synthesizers, instruments far from the areal of traditional Arab organology, along with Western orchestral sound (introduced from Egyptian tarab singers,) replaced the traditional takht, (small Arab ensemble), (George Wassouf, Asab firaq. [The Hardest Parting]). Instruments native to western culture (Rasmussen, 1996), such as guitars, (Fadel Shaker, Ensa elli rah [Forget What Has Passed]), piano (Kathem Al Saher, Ahebini bila oqadi, [Love Me in Quiet Way]), and saxophones (George Wassouf, Hudini Ihanin, [Love Has 
Taken Me]) became a usual part of Arab ethno-pop band, shifting the general sound to Western mimicry. Despite the primary mistrust toward the electric piano, (Aran Music Conference in Cairo, 1932), the org grows into an inseparable part of the modern ethno-pop sound. Nevertheless, traditional instruments as oud, and darabukkah/ tableh, remained staples of the local tradition.

Oriental core of the ethno- pop

Yet, ethno-pop preserved some basic ethno elements, which self-determine its quintessential nature. Apart from Arab language, still relevant is the maqam mode (Ellisa, Hob kul hayati, [The love of my life]; Kathem Al Saher, Ak'raha, [I Hate Her]; Majida Roumi, Kun sadiki, [Be my friend], Omr Diab, El Layla, [The night]); the existence of strong attachment to the darub murakkabeh, or the typical oriental rhythms (Tamer Hosni, Ya Ana Ya Masesh, [Ether me, ether nothing]), in addition to the use of several local instruments such as oud, ney, darabuka, qanun; (Assala, Hany Shaker, Alissa, Melhem Zain, Saber El Rubai, Majid Al Muhandis); and appearance of taqsim (improvisation) in instrumental introductions or interludes (Majida Roumi, Kalimat, [Words]; Hany Shaker, Ghalta, [Mistake]). These elements remain as a bright symbol of ethnic strife, an attempt to represent music as a flag that manifests belonging to a certain ethnic tradition preserving some oriental sense, which determines the local culture as significantly connected to specific musical heritage.

\section{Lyrics}

Popular songs have changed in terms of stanzas, in an attempt to mirror the Western style of composing the texts (Fadi Shaker and Yara, Hudini maak, [Take me with you]; Amr Diab, Gamalo, [The Beauty]). Traditional style of romantic lyrics remains, yet qalimat (words) are lacking the dreamy, nostalgic feelings, typical for classical musiqa tarab. The texts revolve around more simple, charming, daily, even erotic topics. Ethno-pop was observed as collective popular music; as such it carries symbols of daily affairs and more simplified feelings. Lyrics are written in the common tongue Lugha a'mma and are partly following the principles of traditional poetry streaming from fan al tarab. The texts are bright, romantic, but easy to recall, revolving around the individual and community feelings.

\section{Visual presentation}

Product visualization of the ethno-pop has skewed towards a presentation containing a stronger gravitational haul towards the sensitive and hedonistic image of the performers, similarly to the Western pop stars (Saad Lamjarred, Haifa Wahbe, Rubi). In this context, one can refer to Adorno, saying that "Music serves in America today as an advertisement for commodities" (Adorno, 2002, 295). Images of temptresses and 'bad girls' have become the hallmark, and a product of this culture (Dana, Nanny, Haifa Wahbe). These images have gradually transcended the conservative appearance of classical Arab singer and became identified with familiar models from the covers of world fashion magazines, the Hollywood beauties, and models. (Douzi, Saad Lamjareed, Nawal Al Zoghbi). Artists, presented by reality TV shows, such as 'X-factor' or 'The Voice', have become subjects of massive social interest. Depictions of the young generation's idols have been produced as being worthy of imitation and admiration (Kathem Saher, George Yossouf, Nancy Ajram, Myriam Faress). Stylistically, directly, sensually, medially, globally, physically, and virtually, these images have emerged as the after-effect of constitutionalizing communication, possessing its codes, its conventions, and its visual standard.

Significantly, in the world of expanding digital media Arab ethno-pop rapidly lost its credibility as a form of local heritage. Similarly, specific aesthetic understanding, and conventional interpretation of ethnic culture still present and define it as a local phenomenon. Negus noted that popular music is a product of an uninterrupted continuous historical talk in which no one has neither the first nor the last word (Negus, 1996, 138). Proceeding from this stance, one may conclude that we are observing two fine cultural lines appearing within the context by which contemporary Arab ethno-pop music is operating. On one side we can detect a clear connection to specific ethnic musical sense. As Todorova described it "indeed human reality seems to be genuinely divided into clearly different cultures, histories, traditions, societies, even races, and survive the consequences humanity" (Todorova, 1997, 27). Simply said, ethno-pop can be interpreted as local, ethnic music, a product of a certain place and region, and the fruit of folklore tradition. Musical identity can be traced in the importance of the language, dominance of oriental sound based on maqam tradition, use of iqa'at and local rhythmical beats, implementation of traditional instruments, and lyrical texts. On the other hand, this phenomenon is globally branded. Globalization has led to the prominent shifts in the core of Arab popular music, which can be traced in harmonization, shift to vertical linear musical texture, application of intensive, electronic dance beats borrowed from West culture, foreign instruments, and the visual presentation of the musical product. The metamorphosis is induced by several key factors. To begin with, the influence of expanding tourism in the region (Keightley 2004), new technologies (Sterne 2003), commercialism (Brennan 2001, Taylor 2007), and global interconnectedness, which is characterized by dynamic interactions entailing mosaics-like mixtures, thereby dissolving the regional and transforming it into a multi-cultural process of the novel conceptions regarding music, and culture as a whole.

\section{Conclusion}

The great enrapture concerning the interaction between various cultural forms, as well as the query whether the 
converging between the global and the local is producing any consequences, could lead to profound revelations regarding the transformation of identities and the impact of globalism upon cultures. Ethno-pop culture, in the Arab world, appears to be a template of how collaboration between cultures may persuade the creation of a novel style, one which is representative of the wants and needs of young Arabs (as is in the case of Jordanians). This collaboration is important, as its pilots towards the attempt of developing new theoretical terminology based on hybridity and globalization. "We cannot easily discard the word [globalization] in part because, just as modernity, it seems to point to phenomena not easily covered by other words" (Trouillot, 2003, 47). By the end of the twentieth century and the early twenty-first century, a borderline was marked during the formation of music culture in Jordan. It reshapes Arab folklore as a live developing art, into pop-art. Whereby granting space for flickers of new currents and experimentation regarding the aesthetic tastes of the commercialized generation. The appearance of the global network, the compression of both time and space between the creator and the consumer of music products, and the possibility of bringing forth the 'foreign' into the ethnocultural space, have all together led to a fresh socio-musical situation. More specifically, the creation of an eclectic style of music formed by a kaleidoscope of influences, and thereby uprooting the traits of the local ethnic culture. I have decided to use the term 'ethno-pop' when describing this new culture, as it was labeled by the interviewed young Jordanians, and was analyzed in the presented theoretical approach. If one takes in the liberty of reproducing the genre boundaries of the ethno-pop from a historical perspective, this phenomenon would be interpreted as old-age and at the same time a new situation; someone making music and giving aesthetic pleasure to someone else listening to it under the form of sound and movement (in the present, visually improved). I.e. the old-age history of giving hedonistic pleasure within the frameworks of an ancient socio-cultural situation, loaded by a multitude of factors, globalization, communication, commercialism, marketing, and social driving forces. Thereby, the object of Arab ethno-pop has been considered as both a social fact (confirmed by the inquiry), and a cultural phenomenon (discussed as a product of the life constructive power of specific popular taste and preference); being presented with no 'detestation' or profanation, whereby its value of an object in the realm of music has been objectively registered, and the 'mix-up'/'mergers' of cultures and global trends have been shown as part of current Jordanian culture. The most important matter, concluded by the inquiry, is the fact that young Jordanians have recognized and defined ethno-pop as a fusion between local and global influences, and this infiltration is willingly accepted. Young Arabs do cling to their ethnic traditions in musical and stylistic terms, but at the same time they recognize and search for new modern and Western aesthetic models. In conclusion, the young Jordanian generation acknowledges the global impact onto their ethnic music and are not afraid of the vision that future music belongs to a mixed intercultural synthesis, or probably to a single, common cultural heritage.

\section{References:}

Adams, T.M., Fuller, D.B., (2006), The Words have Changes but the Ideology Remains the Same: Misogynistic Lyrics in Rap Music, Journal of Black Studies, Vol.36, (6)

Adorno, T., (2002), Essay of Music, University of California Press

Attali, J., (1985), Noise. The political economy of Music, Minnesota University Press

Ayyash, R., (2002), Broadcasters' Obligations towards their Audiences in Times of Crises, MA theses, Leicester University

Aziz, M., (2010), Arab Music Videos and Their Implication for Arab Music and Media, Music and Media in the Arab World, American University in Cairo press

Bahoken, J.C., Athangana, E., (1976), Cultural Policy in the United Republic of Cameroon, Paris, The UNESCO Press

Bennett, A., Rogers, I, (2016), In the Scattered Fields of Memory: Unofficial Live Music Venues, Intangible Heritage, and the Recreation of the Music Past, Space and Culture, Vol. 19

Bithell, C., (2006), The past in Music: Introduction In the past of music, Ethnomusicology Forum Special issue, Vol. 15, (1)

Boden, M., (2004), The Creative Mind: Myths and Mechanisms, New York

Booth, G, Kuhn, T., (1990), Economic and Transmission Factors as Essential Elements in the Definition of Folk, Art and Pop Music, The Music Quarterly, Vol. 74, (3)

Braudel, F., (1982), The Wheels of Commerce, London

Brennan, T., (2001), World Music Does Not Exist, Discourse Journal of theoretical studies in media and culture, Vol.23, (1)

Briggs, C., Bauman, R., (1992), Genre, Intertextuality and Social Power, Journal of Linguistic Anthropology, Vol.2, (2)

Brunner, A., (2017), Popular Music and the Young Postcolonial State of Cameroon, 1960- 1980, Popular Music and Society, Vol.40, (1)

Butt, J., (2002), Playing with History; The Historical Approach to Musical Performance, Cambridge University press 
Cundiff, G., (2013), The Influence of Rap/Hip-Hop Music: A Mixed Method Analyses on Audience Perceptions of Mesogynistic Lyrics and the Issue of Domestic Violence, Elon Journal of Undergraduate Research in Communication Vol. 4, (1)

Diawara, M., (1998), In search of Africa, Harvard University Press

Dimov, V., (2001), The Ethno-Pop Boom, BAN, Sofia

Feld, S., Charles, K., (1994), Music Grooves, Chicago Press,

Fiske, J., (1992), Understanding Popular Culture, Boston.

Frishkopf, M., (2010), Music and Media in the Arab World, American University in Cairo Press

Gervais-Lambony, Ph. (2006), Space and Identity: Thinking through some South African Examples, Reflection on Identity in Four African Cities, African Minds,

Gilman, D.,(2014), Cairo Pop: Youth Music in Contemporary Egypt, Minneapolis: University of Minnesota Press,

Gourdine, R.M., Lemmons, B., (2011), Perception of Misogyny in Hip-Hop and Rap: What Do the Youths Think? Journal of Human Behaviors in the Social Environment, Vol. 21, (1)

Guilbault, J., (1997), Interpreting World Music: A Challenge in Theory and Practice, Popular Music, Vol. 16, (1)

Harris, R., (2012), Tracks, Temporal Shifts and Transnational Networks of Sentiment in Uyghur Song, Ethnomusicology, Vol. 56, (3)

Hayward, P., (2012), A place in the World: Globalization, Music and Cultural Identity of Contemporary Vanuatu, Music and Globalization, Indiana University Press

Hill, J., (2007), Global Folk Music Fusions: The Reification of Transnational Relationships and the Ethics of Cross-cultural Appropriations in Finnish Contemporary Folk Music, Yearbook for Traditional Music, Vol.39

Keightley, K., (2004), Adventures in Sound: Audio Technology and the Virtual Global, Conference representation, Critical Worlds 1, University of Montreal

Kraidy, M., (2008), Reality Television and Politics in the Arab World: Preliminary Observations, Transnational Broadcasting Studies Vol. 16

Laurent, A., (2007), The Music of the Other: New Challenges for Ethnomusicology in a Global Age, Hampshire, Ashgate,

Lessing, L., (2008), Remix: Making Art and Commerce Thrive in the Hybrid Economy, New York, Penguin Press,

Lohman, L., (2010), Umm Kulthūm: Artistic Agency and the Shaping of an Arab Legend, 1967-2007. Middletown, Wesleyan University Press.

Lopes, P., (1999), Diffusion and Syncretism: The Modern Jazz Tradition, Annals of the American Academy of Political and Social Sciences

Marcus, S., L., (2007), Music in Egypt: Experiencing Music, Expressing Culture, Oxford University Press

Miles, S., (2000), Youth Lifestyle in a Changing World, Buckingham, Open University Press

Morin, E., (1995), The spirit of the time, Myth and Reality, Hristo Botev, Sofia,

Mutaz, A., (2010), Arab Videos and Their Implications for Arab Music and Media, Music and Media in Arab World, American University in Cairo press

Negus, K., (1996), Popular Music in Theory; An Introduction, University Press of New England, Hanover

Nettl, B., (1983 [2005]), The Study of Ethnomusicology; Thirty one issues and concepts, Urbana, Chicago, $2^{\text {nd }}$, University of Illinois Press.

Ortega y Gasser, J., (1989), The Revolt of the Masses, Philosophical questions, Science, Moscow,

Radano, R., Bohlman, P., (2000), Music and the Racial Imagination, University of Chicago Press

Rasmussen, A K., (1996), Theory and practice at the "Arabic org": Digital technology in contemporary Arab Musical performance, Popular Music, Vol. 15, (3)

Reynolods, S., (1998), Generation Ecstasy: Into the World of Techno and Rave Cultures, Psychology Press,

Rowland, J., (2009), Democracy and the Tribal System in Jordan: Tribalism as a Vehicle for Social Change, Independent Study Collection, Duke University

Sabry, T., (2010), Cultural Encounters in the Arab World: On Media, the Modern and the Everyday, London, Tauris,

El Shawan, S., (1980), The socio-political context of al- musiqa al-arabiyyah in Cairo, Egypt; Policies, patronage, institution, and musical change (1927-77) Asian Music 12 (1)

Shannon, J H., (2006), Among the Jasmine Trees: Music and Modernity in Contemporary Syria. Middletown, Wesleyan University Press

Signell, K., (1977), Makam, Modal Practice in Turkish Art Music, Washington, Asian music publication

Slobin, M., (1983), Rethinking 'Revival' of American Ethnic Music, New York folklore, Vol. 9 (3-4)

Sparks, C., (2000), The Global, the Local and the Public Sphere, New Communication Landscape: Demystifying Media Globalization, London

Statelova, R., M., (1991), Folk Music: To the Essence of the Phenomenon and Its Defining, Bulgarian Music Theory magazine, Vol.1, Sofia.

Sterne, J., (2003), The Audible Past: Cultural Origins of Sound Reproduction, Duke University Press 
Story, K., A., (2010), Racing Sex-Sexing Race: The Invention of the Black Feminine Body, In Imagining the Black Female Body, New York, Palgrave Macmillan

Suna, L., (2013), Senior Pop Music? The Role of Folk Like schalager Music for Elderly People, Northern Lights, Vol.11

Teylor, C., (1994), Multiculturalism: Examining the Politics of Recognition, Princeton University Press

Taylor, T., (2007), The Commodification of Music at the Dawn of the Era of Mechanic Music, Ethnomusicology, Vol. 51(2)

Taylor, T., (2012), World Music Today, In Music and Globalization: Critical Encounters, Indiana University Press

Taylor, T., (2013), Globalized New Capitalism and the Commodification of the Taste, The Cambridge History of World Music, Cambridge University Press

Todorova, M., (1997), Imagining the Balkans, New York Oxford University Press

Toop, D., (1995), Ocean of Sound, London,

Trouillot, M., R., (2003), Global Transformation: Anthropology and the Modern World , New York

Valassopoulos, A., Said, M.D., (2014), Popular Protest Music in the 2011 Egyptian Revolution, Popular Music and Society, Vol. 37, (5)

Vassic, O., (1997), The Dance and it Transformance in Samples Chochek and Shota Games, $6^{\text {th }}$ symposium of Folk Music, Sofia.

Wanjala, H., Kebaya Ch., (2017), Popular Music and Identity Formation Among Kenyan Youth, Muziki, Vol. 13, (2)

Whiteley, S., (2004), Introduction 'Music, Space and Place', Music Space and Place: Popular Music and Cultural Identity, Aldershot, Ashgate

Williams, R., (1989), Culture is Ordinary, In Resource of Hope; Culture, Democracy, Socialism, London and New York, Verso,

Zolberg, V., (1990), Constructing the Sociology of the Art, Cambridge University Press,

Tsonka Al Bakri is an associate professor at the University of Jordan, College of Fine Arts and Design, Music Department. She graduated from Bulgarian School of Music "Lubomir Pipkov," Bulgarian Academy of Music"Pancho Vladigerov" instrumental faculty piano, and Ph.D. in musicology. Since the age of 9, she performed solo recitals and concerts with orchestras in Europe and Russia and Turkey and has two gramophone records and one CD. After her transfer to Jordan she performed many concerts and became a piano teacher at the National Music Conservatory, Yarmouk University, when she established the piano department and later at the University of Jordan. She is an author of more than 20 researches in national and international journals covering ethnomusicology, musicology, and methodology. Her scientific work focused mainly on Arab ethnomusicology, piano performance, teaching, and history of music. 